\title{
AFTER INDUSTRIAL SOCIETY?
}

THE EMERGING SELF-SERVICE ECONOMY 


\title{
AFTER INDUSTRIAL SOGIETY?
}

The Emerging Self-service Economy

\author{
Jonathan Gershuny
}

Science Policy Research Unit

University of Sussex 
(C) Jonathan Gershuny 1978

All rights reserved. No part of this publication may be reproduced or transmitted, in any form or by any means, without permission.

First published 1978 by

THE MACMILLAN PRESS LTD

London and Basingstoke

Associated companies in Delhi Dublin

Hong Kong Johannesburg Lagos Melbourne

New York Singapore and Tokyo

The Gresham Press

Old Woking, Surrey

\section{British Library Cataloguing in Publication Data}

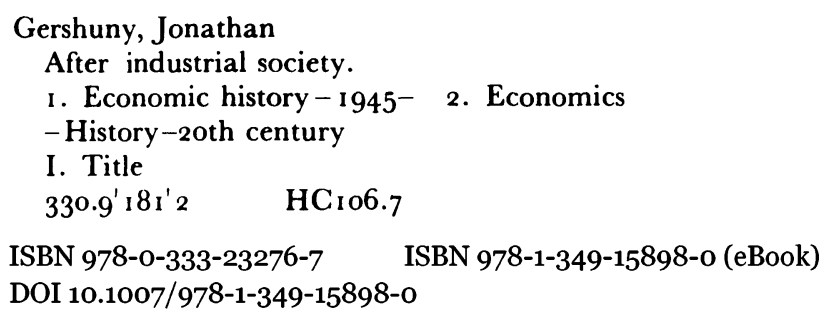

This book is sold subject to the standard conditions of the Net Book Agreement.

The paperback edition of this book is sold subject to the condition that it shall not, by way of trade or otherwise, be lent, resold, hired out, or otherwise circulated without the publisher's prior consent in any form of binding or cover other than that in which it is published and without a similar condition including this condition being imposed on the subsequent purchaser. 
For Esther 


\section{CONTENTS}

Acknowledgements $\quad$ ix

Introduction: After Industrial Society-Some Speculations I

I The Prophets' Problem I

2 Choosing a Future 3

3 Inertial Mechanisms and Social Change 6

4 The Purpose of this Book 8

I The Hinge of History 10

The Second Coming of Post-Industrial

Society? I0

2 Growth or Stability: an Antediluvian Debate I3

3 Growth or Improvement: a Political Question? I 7

2 Some Post-Industrial Themes 20

I Four Modern Improvement Theorists 20

I.I Dahrendorf, The New Liberty 20

I.2 Bell, The Coming of Post-Industrial Society 23

I.3 Galbraith, Economics and the Public Purpose $\quad 28$

I.4 Schumacher, Small is Beautiful $3^{\mathrm{I}}$

2 Six Post-Industrial Themes 33

3 A Buddhist Economics?

I Two Fictional Futures 37

2 Some Questions and Qualifications 45

3 A Social Limit to Growth? 49

$4 \quad$ Towards a Service Economy?

I What are Services?

2 Growing Service Employment 59

3 Service Employment and the Service Economy 
viii CONTENTS

5 The Self-Service Economy

I The Consumption of Services 7 I

2 Substitution of Goods for Services 74

3 Growing Social Expenditure on Services 8 I

4 Where Does This Leave Us? 84

5 Goods or Services? 87

6 Service Employment and Material Production 92

I Productivity and the Tertiary Sector $\quad 92$

2 Changes in Industrial Employment 93

3 Occupations-Goods- or Services-Related? $\quad 98$

4 Too Few Producers? 105

7 What Happens to Jobs?

I Progress and the Degradation of Jobs II

2 Job Degradation and the Division of Labour $\quad$ I 16

3 Occupational Change Since I96 I I 26

4 Job Design and Economic Growth $\quad 132$

8 Conclusion: A Choice of Futures 137

I Findings So Far $\quad$ I 37

2 A View of the Future I4I

3 Three Strategies $\quad$ I 48

Notes and References $\quad$ I53

The Tables and Figures: Sources and Comments $\quad{ }_{167}$

$\begin{array}{ll}\text { Index } & \mathbf{I} 79\end{array}$ 


\section{ACKNOWLEDGEMENTS}

The work on which this book is based was commissioned by the Programmes Analysis Unit, a joint unit of the U. K. Atomic Energy Authority and the Department of Industry. The opinions and arguments found here are, however, entirely those of the author, and are in no way attributable to his sponsors.

A number of people have, at various points, made helpful comments and criticisms: Peter Jones, Keith Taylor and Ken Hill from the P. A. U.; almost all of my colleagues in the Science Policy Research Unit; and in addition Christopher Saunders, Guy Routh, Krishan Kumar and Bernard Cazes. The manuscript was typed, in its various stages, by Sylvia Richards and Melanie Hempleman. 